\title{
Synergy of program strategies on road handling in Denpasar city
}

\author{
Anak Agung Diah Parami Dewi ${ }^{1,}{ }^{*}$, Candra Dharmayanti ${ }^{1}$, and Ida Ayu Widhyanasari ${ }^{2}$ \\ ${ }^{1}$ Department of Civil Engineering, Universitas Udayana, Denpasar, Indonesia \\ ${ }^{2}$ Public Work Department, Denpasar Region
}

\begin{abstract}
Road handling and utility installation in Denpasar City Area are still running based on the work program of each agency and have not yet been integrated. Utility owners conduct system repairs or additions according to consumer demand. However, in the implementation, they do not synergize with the road organizer program. The restoration of road pavement conditions is not optimal and has potential to damage the utility system as a result of these circumstances. This study aims to analyze the existing conditions, the synergy program constraints, and the correct strategies to synergize road handling and utility system installation. Data were collected using questionnaire survey, interview, and focus group discussion. Purposive sampling method was chosen to select respondents. Subsequently, the data collected were analyzed using qualitative descriptive and SWOT analysis. The results of the analysis show that synergistic conditions have not been implemented. The constraints faced by the program synergy are the ineffectiveness of coordination and collaboration between relevant stakeholders, ineffectiveness of stakeholder involvement, lack of vision and mission of stakeholders to make changes, stakeholders being reluctant to change, budget constraints, lack of stakeholder innovation, operational and maintenance costs of integrated projects, and relatively large and stakeholders have not initiated integrated project management. The strategies undertaken to create program synergy are: preparing regional regulations and regulations, forming joint teams, synergizing road and utility network databases, creating pilot projects and setting up an online complaints service.
\end{abstract}

\section{Introduction}

Road infrastructure facilities and utility systems are essential requirements for people in urban areas, and the government has a responsibility to fulfill such need. The government has authorization and obligation to be a road organizer. Road organizers carry out activities of regulating, instructing, building, and controlling regarding road infrastructure. The implementation of road infrastructure in Denpasar City has been the authority of the central government, the Bali Provincial Government and the Denpasar City Government. Road operations are carried out following the authority of each agency for the road assets owned.

\footnotetext{
*Corresponding author: diahparami@civil.unud.ac.id
} 
Road organizers regulate the use of spaces on the road, including the installation of a utility system.

Currently, many of the main road segments in the city of Denpasar often experience patches due to the excavation of utility systems. Consequently, this leads to disruption of road users. The road infrastructures and the water pipe system become damaged, and the road function experiences deterioration.

Program synergy between road operating and utility installations is an integrated program to fulfill road infrastructure services and other supporting facilities. Local governments and utility system agencies should synergize in carrying out the programs, starting from planning, implementation, and supervision to achieve corporate goals. Road handling in the area of Denpasar City has not been entirely carried out along with the installation of the utility systems. Program synergy between the local government and the utility system authorities has not yet been carried out. The role and commitment of stakeholders in handling the road thoroughly and in synergy have not yet been seen. The problems that occur have an impact on the community's assessment of the government's unplanned and integrated performance and give the impression of budget waste.

Road operating and the use of road parts that are not conducted through organized planning, implementation and supervision between several agencies that utilize the road part have a terrible impact on the budget and community assessment of the performance of government services, such as inefficiency, unreliability, discomfort for road users, and a lack of safety and sustainability.

Therefore, this study was conducted to analyze the existing road operations and utility system installation conditions, the barriers to conducting program synergy in road infrastructure, and the strategies that must be implemented to realize the synergy of the program in operating the road and installation of a utility system in the area of Denpasar City. This study is beneficial to provide information and ideas that can be used as input for relevant agencies in carrying out road handling and installation of utility networks in Denpasar City.

\section{Road organising}

Program synergy is an integrated program or collaborative program of several sectors that is carried out cooperatively to achieve mutual goals. The synergy between agencies is one of the components of success in integrated development to make better results [1]. Based on this opinion, the synergy was carried out by several parties and sectors to combine existing elements. Synergy is carried out jointly to achieve better results or outputs of activities than previous achievements. The joining of several systems in a program is conducted to complete the elements possessed by each party involved in synergy. The program aims to optimize the result of mutually agreed activities. Synergy is conducted because of the need to improve on the achievement of previous activities and should be carried out jointly by the parties involved.

Program synergy, which starts from the financing and implementation process, should not only be dominated by one stakeholder. Communication and coordination between stakeholders must be developed in two directions. Communication and coordination that obtain action and reaction from other stakeholders indicate that there is a need for integration in the desired activity program. Program synergy can be implemented if there is a mutual goal between the stakeholders involved. The success and achievement of the program goals must be followed by the synergy of stakeholders in implementing programs [2]. The implementation of the synergy program activities can be done through four stages, namely: identification of needs stage, preparation stage, implementation stage, and evaluation stage [3]. The synergy of program activities for public services requires strong 
support from stakeholders [4]. The integrated program or program synergy can be initiated by further improving cross-program, cross-sector coordination and communication, and involving potential stakeholders [5]. Coordination requires strategies, commitment, and consequences to achieve organizational goals effectively and efficiently. Coordination and communication developed in the synergy of the program need integrated management to achieve mutual goals.

Program synergy in operating road infrastructure and utility systems can be implemented through appropriate communication and coordination between stakeholders (related agencies). Communication is a method to deliver purpose and aspiration regarding ideas and information between parties [6]. Communication is the process of exchanging information, trust, and feelings between members to realize mutual understanding and trust to create a good relationship [7,8]. Coordination is a form of work relationship that has similar integration, synchronization, integration, harmony, and direction. Coordination is the harmonization, alignment, and unification of actions of a group of people that are mutually integrated towards mutual goals [9].

Barriers to program synergy in operating road utility installation programs have caused problems from various aspects that are directly experienced by the stakeholders involved. The problem in operating roads and installing utilities can be solved by analyzing the appropriate strategies to overcome them. Definition of strategy is a way, pattern and technical means conducted to utilize the resources owned by an organization to achieve its goals [10].

\section{Method}

This research was carried out by a descriptive method supported by qualitative data. Data collection was carried out using questionnaires, interviews, and FGDs which were distributed to stakeholders involved in the road operating and utility installation program in Denpasar City. The sample selection is based on a purposive sampling method. Samples include echelon 2, 3, and 4 officials in government agencies that handle 13 road operations, as well as 11 officials from utility providers PLN, PDAM, and Telkom.

\section{Results and discussion}

\subsection{Barriers to operating roads}

The result from interviews with stakeholders in Table 1 shows the identification of barriers to the implementation of program synergy in operating road infrastructure and utility installations in the Denpasar City area, which include: 1) ineffectiveness of coordination and collaboration between relevant stakeholders, 2) ineffectiveness of stakeholders' involvement in making decisions, 3) lack of vision and mission of stakeholders to make changes, 4) stakeholders are reluctant to change because they already feel in a comfort zone, 5) limited budget to create integrated programs in operating roads in Denpasar City, 6) lack of innovation of stakeholders in repairing and operating road infrastructure, 7) operational and maintenance costs of integrated projects are relatively high, and 8) absence of stakeholders who have initiated integrated project management. There are different opinions on indicator number 6 , as the road organizer argues that they have made innovations in the improvement and operating of road infrastructure. On the other hand, the owner of the utility argues that they have not implemented this. This difference of opinion strengthens the existence of problems that have not yet undergone synergy in the implementation of road and utility handling due to the constraints mentioned above. 
Table 1. Opinions of road operators and utility owners regarding the synergistic constraints of the program handling of roads and installation of utilities in the Denpasar City area.

\begin{tabular}{|c|c|c|c|c|c|}
\hline \multirow{2}{*}{ No } & \multirow{2}{*}{ Description } & \multicolumn{2}{|c|}{ Road organizer } & \multicolumn{2}{|c|}{$\begin{array}{l}\text { Utility System } \\
\text { Agency }\end{array}$} \\
\hline & & Agree & Disagree & Agree & Disagree \\
\hline 1. & $\begin{array}{l}\text { Ineffective coordination and } \\
\text { collaboration between relevant } \\
\text { stakeholders }\end{array}$ & 10 & 2 & 6 & 4 \\
\hline 2. & $\begin{array}{l}\text { Ineffectiveness of stakeholders in } \\
\text { making decisions }\end{array}$ & 11 & 1 & 6 & 4 \\
\hline 3. & $\begin{array}{l}\text { There is no vision and mission from } \\
\text { stakeholders to make changes }\end{array}$ & 11 & 1 & 10 & 1 \\
\hline 4. & $\begin{array}{l}\text { Stakeholders who are reluctant to change } \\
\text { because they already feel in a comfort } \\
\text { zone }\end{array}$ & 10 & 2 & 11 & \\
\hline 5. & $\begin{array}{l}\text { Limited budget to create an integrated } \\
\text { program in handling roads in Denpasar } \\
\text { City }\end{array}$ & 11 & 1 & 6 & 3 \\
\hline 6. & $\begin{array}{l}\text { Lack of stakeholders' innovation in } \\
\text { repairing and handling road } \\
\text { infrastructure }\end{array}$ & 3 & 9 & 7 & 4 \\
\hline 7. & $\begin{array}{l}\text { Operational and maintenance costs of } \\
\text { integrated projects are relatively large }\end{array}$ & 8 & 4 & 9 & 2 \\
\hline 8. & $\begin{array}{l}\text { No stakeholders have initiated integrated } \\
\text { project management }\end{array}$ & 5 & 7 & 6 & 5 \\
\hline
\end{tabular}

\subsection{Program synergy strategies}

Based on the SWOT analysis, the program synergy strategy plan that can address the problems from various aspects of road handling and utility installation in Denpasar City is shown in Table 2 below.

Table 2. Strategic plans for road management and utility installation in Denpasar City Area.

\begin{tabular}{|c|c|c|c|}
\hline \multirow{2}{*}{ Barriers } & \multirow{2}{*}{ Plan Format } & \multicolumn{2}{|c|}{ Strategy Plan } \\
\hline & & Short Term & Long Term \\
\hline $\begin{array}{l}\text { Institutional Aspects: } \\
\text { - There is no Regional } \\
\text { Regulation that regulates } \\
\text { the rights and obligations } \\
\text { of utility owners } \\
\text { - There are no sanctions } \\
\text { in the implementation }\end{array}$ & $\begin{array}{l}\text { Road organizers as regulators } \\
\text { make local regulations } \\
\text { governing rights, obligations } \\
\text { and levies for utility owners } \\
\text { who use the road part, so that it } \\
\text { can increase PAD } \\
\text { Applying sanction rules, }\end{array}$ & $\begin{array}{l}\text { - Making regional } \\
\text { regulations } \\
\text { - Implementation of } \\
\text { coaching and sanctions } \\
\text { for those who violate } \\
\text { - Forming a joint team }\end{array}$ & $\begin{array}{l}\text { - There are regional } \\
\text { regulations } \\
\text { - Obedience of } \\
\text { utility owners } \\
\text { - Road handling, } \\
\text { road repairs, utility }\end{array}$ \\
\hline
\end{tabular}




\begin{tabular}{|c|c|c|c|}
\hline \multirow{2}{*}{ Barriers } & \multirow{2}{*}{ Plan Format } & \multicolumn{2}{|c|}{ Strategy Plan } \\
\hline & & Short Term & Long Term \\
\hline $\begin{array}{l}\text { - The function of the } \\
\text { road operator has not run } \\
\text { optimally } \\
\text { - Intensive coordination } \\
\text { and communication has } \\
\text { not gone well } \\
\text { - Lack of innovation to } \\
\text { make changes }\end{array}$ & $\begin{array}{l}\text { providing guidance to utility } \\
\text { owners who utilize the road } \\
\text { section, so that the findings of } \\
\text { the violation are reduced and } \\
\text { the control and supervision } \\
\text { functions are carried out } \\
\text { Improving communication and } \\
\text { coordination between road } \\
\text { organizers and utility owners, } \\
\text { increasing the compliance of } \\
\text { utility owners for the } \\
\text { management of synergized } \\
\text { network databases } \\
\text { Road organizers issue } \\
\text { regulations in the form of local } \\
\text { regulations that regulate rights } \\
\text { and obligations between road } \\
\text { operators and utility owners in } \\
\text { handling roads, installing and } \\
\text { repairing utility networks to } \\
\text { improve services to the public } \\
\text { and minimize public } \\
\text { complaints }\end{array}$ & $\begin{array}{l}\text { between road } \\
\text { operators and utility } \\
\text { owners who are tasked } \\
\text { with planning, } \\
\text { implementing and } \\
\text { supervising integrated } \\
\text { utilities }\end{array}$ & $\begin{array}{l}\text { Synergy of } \\
\text { installations and } \\
\text { repair of utilities }\end{array}$ \\
\hline $\begin{array}{l}\text { Technical Aspects: } \\
\text { - Land limitations } \\
\text { - Database has not been } \\
\text { synergized } \\
\text { - Non-optimal return } \\
\text { conditions, not according } \\
\text { to technical } \\
\text { specifications } \\
\text { - Lack of supervision } \\
\text { function, } \\
\text { - Deviation of findings }\end{array}$ & $\begin{array}{l}\text { Provide space for utilities, } \\
\text { synergize road and utility } \\
\text { databases so that there are no } \\
\text { irregularities in the installation } \\
\text { and repair of utilities, which } \\
\text { can reduce road performance } \\
\text { and public complaints } \\
\text { Applying sanction rules, } \\
\text { providing guidance to utility } \\
\text { owners who utilize the road } \\
\text { section, so that the findings of } \\
\text { the violation are reduced and } \\
\text { the control and supervision } \\
\text { functions are carried out }\end{array}$ & $\begin{array}{l}\text { - Create integrated } \\
\text { utility design and pilot } \\
\text { projects } \\
\text { - Synergize database } \\
\text { - Form a joint team in } \\
\text { planning, } \\
\text { implementing and } \\
\text { supervising integrated } \\
\text { utilities } \\
\text { - Implement coaching } \\
\text { and sanctions for those } \\
\text { who violate }\end{array}$ & $\begin{array}{l}\text { - Integrated utility } \\
\text { dimensions } \\
\text { according to } \\
\text { available land and } \\
\text { utility requirements } \\
\text { - Database } \\
\text { synergized / } \\
\text { integrated } \\
\text { - Joint supervision } \\
\text { function is well- } \\
\text { implemented } \\
\text { - Increase the } \\
\text { compliance of the } \\
\text { owner of the utility }\end{array}$ \\
\hline $\begin{array}{l}\text { Economic Aspects: } \\
\text { - Limited funds } \\
\text { - Damage to State assets } \\
\text { - Reduced tourist visits } \\
\text { - PAD decreases }\end{array}$ & $\begin{array}{l}\text { Levies are carried out on utility } \\
\text { owners so they can increase } \\
\text { PAD to overcome budget } \\
\text { constraints and can innovate to } \\
\text { prepare space for utility } \\
\text { networks }\end{array}$ & $\begin{array}{l}\text { - Retribution for utility } \\
\text { owners } \\
\text { - Retribution levies to } \\
\text { build integrated } \\
\text { utilities (scrolling) }\end{array}$ & $\begin{array}{l}\text { - Increased PAD } \\
\text { - Increased } \\
\text { development of } \\
\text { integrated utilities }\end{array}$ \\
\hline $\begin{array}{l}\text { Social and } \\
\text { Environmental Aspects } \\
\text { - Handling network } \\
\text { installation and repair } \\
\text { services that are not fast } \\
\text { enough to implement }\end{array}$ & $\begin{array}{l}\text { Building more intensive } \\
\text { communication and } \\
\text { coordination between road } \\
\text { operators and utility owners in }\end{array}$ & $\begin{array}{l}\text { - Set up a quick } \\
\text { complaint response } \\
\text { service online }\end{array}$ & $\begin{array}{l}\text { - Complaints of } \\
\text { problems in the field } \\
\text { can be handled }\end{array}$ \\
\hline
\end{tabular}




\begin{tabular}{|c|c|c|c|}
\hline \multirow{2}{*}{ Barriers } & \multirow{2}{*}{ Plan Format } & \multicolumn{2}{|c|}{ Strategy Plan } \\
\hline & & Short Term & Long Term \\
\hline $\begin{array}{l}\text { - Increased public } \\
\text { complaints } \\
\text { - Increased accidents } \\
\text { - Increased air pollution } \\
\text { - Reduced public trust in } \\
\text { government performance } \\
\text { - The aesthetics of the } \\
\text { area change } \\
\text { - Road damage increases } \\
\text { so that road performance } \\
\text { decreases }\end{array}$ & $\begin{array}{l}\text { carrying out their respective } \\
\text { programs for the integration of } \\
\text { services for the community } \\
\text { The road operator gives } \\
\text { permission by increasing the } \\
\text { compliance of the utility owner } \\
\text { to keep participating in } \\
\text { maintaining the urban area }\end{array}$ & $\begin{array}{l}\text { - There is an official } \\
\text { statement on the } \\
\text { permit to maintain the } \\
\text { aesthetics of the face } \\
\text { of the city during } \\
\text { implementation }\end{array}$ & $\begin{array}{l}\text { quickly } \\
\text { - City aesthetics are } \\
\text { maintained }\end{array}$ \\
\hline
\end{tabular}

\section{Conclusions}

Based on the results and discussion above it can be concluded as follows. Identifiable constraints that make it difficult to realize program synergy in handling roads and installing utility networks in the Denpasar City area are: ineffectiveness of coordination and collaboration between relevant stakeholders, ineffectiveness of stakeholders in making decisions, lack of stakeholders' vision and mission to make changes, stakeholders are reluctant to change because they already feel in a comfort zone, budget constraints to create integrated programs in handling roads in Denpasar City, lack of stakeholders' innovation in repairing and handling road infrastructure; operational and maintenance costs of integrated projects are relatively large, there are no stakeholders who have initiated integrated project management. Strategies that must be implemented to realize program synergy in handling roads and installing utility networks in Denpasar City are:

1. The short-term strategy plan is as follows:
a. Develop regional regulations that contain rights, obligations, retributions, and sanctions in handling roads and installation of utility networks.
b. Implement the process of coaching and sanctions for those who violate.
c. Forming a joint team between road operators and utility owners in charge of planning, implementing, and supervising integrated utilities
d. Create integrated utility design and pilot projects.
e. Synergize database.
f. Retribution levies to build integrated (rolling) utilities.
g. Set up a quick complaint online response service.

2. The long-term strategy plan is:

a. Regional regulations.

b. Obedience of utility owners increases.

c. Synergize road handling, road repairs, utility installations and repairing utilities.
d. There is a standard dimension of integrated utility design according to available land and utility needs.

e. The database is synergized/ integrated.

f. The joint supervision function is well-implemented.

g. Increased PAD.

h. Increased development of integrated utilities.

i. Complaints of problems in the field can be handled quickly.

j. City aesthetics are maintained. 
Based on the conclusions, it is suggested that the road operators in the Denpasar City area become the driving force for the realization of the synergy of the joint program in handling roads and installing utility networks. The initial stage is to devise local regulations that regulate rights, obligations, retributions, and sanctions in handling roads and installation of utility networks. A team should be formed that has a routine duty to coordinate and communicate intensively to plan, implement and supervise the use of road parts. Road operators in the Denpasar City area should immediately set up an integrated utility pilot project.

\section{References}

1. Najiyati and Rahmat, Jurnal Ketransmigrasian 28, (2011)

2. T. Rahmawati, I. Noor, I. Wanuswamatie, Jurnal Administrasi Publik 2, 4 (2014)

3. M. Hasbi, Ad'ministrare 3, 1 (2016)

4. B. R. Aditya, Sarwono, M. Rozikin, Jurnal Administrasi Publik 2, 3 (2014)

5. D. Mulyana, Ilmu komunikasi: Suatu pengantar (PT Remaja Rosdakarya, Jakarta, 2008)

6. F.R. David, Strategik manajemen strategi konsep (Salemba Empat, Jakarta, 2011)

7. R.E. Freeman, Strategic management: A stakeholder approach (Pitman, Boston, 1984)

8. F. Hamid, H. Budianto, Ilmu komunikasi sekarang dan tantangan masa depan (Kecana Prenada Media Group, Jakarta, 2011)

9. K. Karaatanasov, Integrated project management IPM (Without IPPD) (2015)

10. M. West, Effective team work (Kanisius, Yogyakarta, 1998) 